\title{
The Effect of Insemination Time, Season and Insemination Method on Calf Gender in Holstein Cattle
}

\author{
Gokhan Gokce (Corresponding author) \\ Cukurova University, Faculty of Agriculture, Department of Animal Science, Adana, Turkey \\ E-mail: gokhan046@gmail.com \\ https://orcid.org/0000-0001-6980-8989 \\ G. Tamer Kayaalp \\ Cukurova University, Faculty of Agriculture, Department of Animal Science, Adana, Turkey \\ E-mail: tamer.kayaalp@gmail.com \\ https://orcid.org/0000-0003-2193-848X \\ Serap Goncu \\ Cukurova University, Faculty of Agriculture, Department of Animal Science, Adana, Turkey \\ E-mail: serapgoncu66@gmail.com \\ https://orcid.org/0000-0002-0360-2723
}

\begin{abstract}
The aim of this article is to determine the effect of insemination time, season and insemination method on calf gender in cattle. In the study, 792 records of inseminations and calving data between 2010-2019 were evaluated. The onset of estrus was determined based on mounting behavior. Inseminations were carried out between 0-6, 6-12, 12-18 hours after the onset of estrus. At the same time, inseminations were evaluated according to the seasons. Of the inseminations, 582 were artificial insemination and 210 were natural insemination. While insemination time and insemination method had no effect on calf gender, seasonal effect was found to be significant.
\end{abstract}

Keywords: Holstein, Insemination Time, Gender

DOI: $10.7176 / \mathrm{JSTR} / 7-10-03$

\section{Introduction}

The desire to control the gender of animals is more or less as old as domestication. There are many beliefs on this subject from antiquity to the present day. This process, which has attracted the attention of mankind since the beginning of written history and started with empirical methods, seems to keep scientists busy for a longer time, although it continues with highly developed methods today (Kara and Bekyürek, 2020).

Probability theory states that the secondary gender ratio, the male to female ratio at birth, is 50:50 (Khan, 2015). However, predetermining the gender of the offspring to be born in dairy cattle breeding brings some advantages in breeding. Gender determination allows the production strategies and biotechnological work programs of dairy farms to be planned in advance (Erten and Y1lmaz, 2012). In addition, it is clear that any practice affecting the gender ratio will contribute to the rapid increase of genetic capacity in animal breeding.

Many factors have been associated with differences in gender ratios of mammals. These factors include diet, season, illness, hormone levels, insemination time, social status, stress, and age. Variation in gender ratio in response to environmental or physiological conditions can give animals the ability to adapt and thus help ensure the survival of the species. Manipulating conditions that affect the gender ratio to produce preferably male or female offspring will provide economic benefits to livestock producers. However, the reports in the literature and the marked differences between species make it difficult to determine what factors might have contributed to changes in gender ratio in livestock (Huck et al. 1993; Krackow and Burgoyne, 1998; Pratt et al. 1987; Verme and Ozoga, 1981).

20| P a g e

www.iiste.org 
The aim of this study is to investigate whether there is dependence between insemination time, season, and insemination method and calf gender.

\section{Material and Method}

In the study, 792 records of inseminations and births that took place between 2010-2019 in Çukurova University Faculty of Agriculture Research and Application Farm Dairy Cattle Unit were evaluated.

Detection of heat was routinely determined by technicians three times a day by observation. The onset of estrus was determined on the basis of mounting behavior. Inseminations were carried out between 06, 6-12, 12-18 hours after the onset of estrus. At the same time, inseminations were evaluated according to the seasons (Spring; March, April, May, Summer; June, July, August, Autumn; September, October, November, Winter: December, January, February). Of the inseminations, 582 were artificial insemination and 210 were natural insemination. The data were evaluated using the Chi-Square dependency test in the SPSS $22 \mathrm{~V}$ package program.

\section{Results}

\subsection{Insemination Time Gender}

The relationship between insemination time and gender is given in Table 1. In the inseminations performed within 0-6, 6-12 and 12-18 hours after the onset of estrus, the ratio of female-male offspring was determined as 50.2-49.8\%, 52-48\% and 47-53\%, respectively. Although the obtained results show that proportionally more females are obtained in early insemination, the dependence between insemination time and gender was not statistically significant $(p>0,05)$.

Table 1. Number of female, male offspring and gender ratio by insemination time

\begin{tabular}{|l|c|c|c|c|c|c|c|}
\hline $\begin{array}{l}\text { insemination time } \\
\text { /hours }\end{array}$ & Female & Male & Female \% & Male \% & $\mathbf{X}^{\mathbf{2}}$ & SD & p \\
\cline { 1 - 5 } $0-6$ & 151 & 150 & 50.2 & 49.8 & & & \\
\cline { 1 - 5 }-12 & 89 & 83 & 52 & 48 & 3,705 & 2 & 0,150 \\
\hline $12-18$ & 149 & 170 & 47 & 53 & & & \\
\hline
\end{tabular}

\subsection{Season and Gender}

The relationship between season and gender is given in Table 2. Considering inseminations according to the seasons, the rates of female and male offspring obtained from these inseminations were determined as $46-54 \%$ in spring, $35-65 \%$ in summer, $56-44 \%$ in autumn and $58-42 \%$ in winter, respectively. The results obtained showed that more male offspring were obtained in the warmer months. At the same time, this difference was found to be statistically significant.

Table 2. Number of female and male offspring and gender ratio by seasons

\begin{tabular}{|l|c|c|c|c|c|c|c|}
\hline Seasons & Female & Male & Female \% & Male \% & $\mathbf{X}^{\mathbf{2}}$ & SD & p \\
\hline Spring & 98 & 115 & 46 & 54 & & & \\
\cline { 1 - 6 } Summer & 34 & 64 & 35 & 65 & \multirow{3}{*}{18,448} & \multirow{2}{*}{3} & \multirow{2}{*}{0,000} \\
\cline { 1 - 5 } Autumn & 106 & 84 & 56 & 44 & & & \\
\hline Winter & 168 & 123 & 58 & 42 & & & \\
\hline
\end{tabular}

\subsection{Insemination Method and Gender}

The relationship between insemination method and gender is given in Table 2 .

Table 3. Female, male numbers and gender ratio according to the insemination method

\begin{tabular}{|l|c|c|c|c|c|c|c|}
\hline $\begin{array}{l}\text { Insemination } \\
\text { method }\end{array}$ & Female & Male & Female \% & Male \% & $\mathbf{X}^{\mathbf{2}}$ & SD & p \\
\cline { 1 - 5 } $\begin{array}{l}\text { Artificial } \\
\text { insemination }\end{array}$ & 277 & 305 & 47 & 53 & 0,033 & 1 & 0,872 \\
\hline Natural mating & 101 & 109 & 48 & 52 & \\
\hline
\end{tabular}


It was determined that the female-male ratio was $47-53 \%$ in the offspring born as a result of artificial insemination, and the female-male ratio was $48-52 \%$ as a result of natural mating. A dependency between insemination method and gender could not be determined statistically ( $p>0,05)$.

\section{Discussion}

Different results were reported in studies examining the offspring gender of the insemination time. Some researchers stated that more female offspring were obtained with early mating and more male offspring were obtained with late mating (Martinez et al. 2004; Tefsu et al. 2014; Rorie, 1999; Verme and Ozoga, 1981; Wehner et al. 1997). On the contrary, some researchers found that there was no relationship between insemination time and offspring gender ratio (Ballinger, 1970; Bayril and Y1lmaz, 2013; Bayril et al. 2016; Demiral et al. 2007; Foote, 1977; Pursley et al. 1998; Roelofs et al. 2006 Rorie et al. 1999).

Similarly, in our study, it was found that there was no relationship between insemination time and calf gender.

In this study, the dependency between season and offspring gender was found to be statistically significant $(p<0,05)$. It was determined that the number of male calves increased with the increase of air temperature. Similar results to these results have been reported by some other investigators (Roche et al. 2006; Singh et al. 2004; Skjervold et al. 1978).

Roche et al., 2006 reported that the physiology that supports the relationship between season and gender is unknown, but this change in gender ratios is nutrition, pre-pregnancy maternal body condition score. Trivers-Willard (1973) argues that if the environmental conditions are limited, the parents will give importance to the female individuals for the survival of the species, and the opposite happens when the environmental conditions are good.

On the other hand, some researchers reported that there was no relationship between season and offspring gender (Goshu and Singh, 2013; Lari, 2006; Mukherjee et al. 2000; Kaygisız and Vanl1, 2008; Rahman et al., 2002; Y1lmaz et al. 2010).

In our study, a statistically significant relationship was not detected in the offspring born as a result of artificial insemination, although numerically more males were obtained $(\mathrm{P}>0.05)$.

Some researchers stated that the number of male offspring increased with artificial insemination (Berry and Cromie, 2006), some researchers stated that the number of female offspring increased (Arega and Chalchissa, 2019; Bekele, 2005; Tesfu et al., 2014) and some researchers stated that artificial insemination did not affect the offspring gender reported (Delesa et al., 2014; Khan et al., 2015; Tesfu et al., 2014).

As a result, it was determined that insemination time and insemination method did not affect calf gender in cattle, but season had an effect on calf gender.

\section{References}

[1] Arega, A. and Chalchissa, G., 2019. Calves Sex Ratio in Artificial and Naturally Bred Cattle at Adami Tulu Agricultural Research Center. Journal of Biology, Agriculture and Healthcare, Vol.9, No.1, 2019. ISSN 2224-3208 (Paper) ISSN 2225-093X (Online).

[2] Ballinger, H.J., 1970. The effect of inseminations carried out early or late in estrus on the gender ratio of calves born. Vet. Rec., 86: 631.

[3] Bayril, T. And Yılmaz, O., 2013. Effect of timing of artificial insemination after synchronization of ovulation on reproductive performance in Holstein dairy cows. Trop Anim Health Prod (2013) 45:411-416

[4] Bayril, T., Yılmaz, O. and Cak, B., 2016. Effect Of Timing Of Artificial Insemination Relative To Spontaneous Estrus On Reproductive Performance And Calf Gender Ratio In Repeat Breeder Holstein Cows. The Journal Of Animal and Plant Sciences, 26(4): 2016, Page: 924-930 Issn: 1018-7081

[5] Bekele, T., 2005. Calf Sex Ratios in Artificially Inseminated and Natural Mated Female Crossbred Dairy Herd. In: proceedings of the $13^{\text {th }}$ annual conference the Ethiopian Society of Animal Production. Addis Ababa, Ethiopia, pp: 225-230.

22 | P a g e

www.iiste.org 
[6] Berry, D.P. and A.R. Cromie, 2006. Artificial insemination increases the probability of a male calf in dairy and beef cattle. Theriogenology, pp: 1-7.

[7] Delesa EK, Yohannes A, Alemayehu M, Samuel T, Yehualaeshet T., 2014. Calves' gender ratio in naturally and artificially bred cattle in central Ethiopia. Theriogenology. 2014 Aug;82(3):433-9. doi: 10.1016/j.theriogenology.2014.04.027. Epub 2014 May 9. PMID: 24908336.

[8] Demiral, O. ,Ün, M., Abay, M., Bekyürek, T., 2007. The effect of artificial insemination timing on the gender ratio of offspring and fertility in dairy cows. Turk. J. Ve. Anim. Scie., 31(1): 21-24.

[9] Erten, Ö. ve Yılmaz, O. 2012. Süt Sı̆̆ırı Yetiştiriciliğinde Cinsiyeti Belirlenmiş Buzağı Üretim Teknikleri .YYU Veteriner Fakültesi Dergisi, 2012, 23 (3), 155 - 157.

[10] Foote, R.H., 1977. Sex ratios in dairy cattle under various conditions. Theriogenology, 8: 349-356.

[11] Goshu G., Singh H., 2013. Genetic and non-genetic parameters of replacement rate component traits in Holstein Friesian cattle. Springer Plus 2, 581.

[12] Huck UW, Seger J, Lisk RD., 1993. Litter gender ratios in the golden hamster vary with time of mating and litter size and are not binomially distributed. Behav Ecol Sot 1993;26:99109.

[13] Kara, U., Bekyürek, T. (2020). Türkiye'de Süt Sığırcılığında Reprodüktif Biyoteknolojik Yöntemlerin Gelişimi. International Journal of Eastern Mediterranean Agricultural Research, $3(1): 63-82$

[14] Kaygisiz A., Vanli Y., 2008. Factors influencing gender ratio in Brown Swiss cattle. Indian J. Anim. Sci. 78, 656-657.

[15] Khan, I.M., Jalali, S., Shahid, B., Shami, S.A., 2015. Effect of Artificial Insemination and Natural Service on Calf Sex Ratio in Dairy Cattle. Proceedings of the Pakistan Academy of Sciences 52 (1): 63-66 (2015). ISSN: 0377 - 2969 (print), 2306 - 1448 (online)

[16] Krackow S, Burgoyne PS.1998. Timing of mating, developmental asynchrony and gender ratio of mice. Physiol Behav 1998;63:81-84.

[17] Lari M.A., 2006. Sex ratio at birth in dairy herds in Fars province, southern Iran. Trop. Anim. Health Prod. 38, 593-595.

[18] Martinez, F., M. Kabbi, F. Martinez-pastor, M. Alvarez, E. Anel, J. Boixo, P.Depaz and L. Anel, 2004. Effect of the interval between estrus onsets and artificial insemination on gender ratio and fertility incattle: a field study. Theriogenology, 62: 1264-1270.

[19] Mukherjee, K., S.S Tomar and R.B. Singh, 2000. Variability in gender ratio in Karan Swiss cattle. Indian Journal of Animal Research34, 24-28 (2000).

[20] Pratt NC, Huck UW, Lisk RD. , 1987. Offspring gender ratio in hamsters is correlated with vaginal $\mathrm{pH}$ at certain times of mating. Behav Neural Biol 1987;48:3 10-3 16.

[21] Pursley, J.R., R.W. Silcox and M.C. Wiltbank, 1998. Effect of time of artificial insemination on pregnancy rates, calving rates, pregnancy loss and gender ratio after synchronization of ovulation in lactating dairy cows. J. Dairy Sci., 81: 2139-2144. 
[22] Rahman, M.M., M.N. Islam, S. Faruque and B.K. Roy, 2002. Effect of season on the gender ratio and calving frequency of cattle under farm conditions. Journal of Biological Science 2: 160-161 (2002).

[23] Roche, J.R., J.M. Leeand D.P. Berry, 2006. Climatic factors and secondary gender ratio in dairy cows. J Dairy Sci., 89: 3221-7.

[24] Roelofs, J.B., Bouwman, E.B., Pedersen, H.G., Rasmussen, Z.R., Soede, N.M., Thomsen, P.D. and Kemp, B., 2006. Effect of time of artificial insemination on embryo gender ratio in dairy cattle. Anim. Reprod. Sci., 93, 366-371.

[25] Rorie, R.W., T.D. Lester, B.R. Lindsey and R.W. McNew, 1999. Effect of timing of artificial insemination on gender ratio in beef cattle. Theriogenology, 52: 1035-1041.

[26] Singh, B., D. Kumar, H. Singh, R.B. Prasad and J.B. Singh, 2004. Genetic studies on gender ratio in dairy cattle. Indian Journal of Animal Science 74: 986-988 (2004).

[27] Skjervold, H. and J. James, 1978. Causes of variation in the gender ratio in dairy cattle. Zeit Tier Zuch, 95: 293-305.

[28] Tesfu, F., Gebrekidan, B. and Afera, B. 2014. Assessment and Comparison of Sex Ratio Following Artificial Insemination and Natural Mating in Small Scale and Modern Dairy Cattle Farms in Mekelle. Journal of Reproduction and Infertility 5 (2): 58-64, 2014 ISSN 2079-2166.

[29] Trivers,R.L.andWillard,D.E.,1973. Natural selection of parentalability to vary the gender ratio of off spring.Science179,90-92 (1973)

[30] Verme LJ, Ozoga JJ., 1981. Sex ratio of white-tailed deer and the estrus cycle. J Wild Manage 1981;45:710-715.

[31] Wehner, G., C. Wood, A. Tague, D. Barker andH. Hubert, 1997. Efficiency of the ovatec unit forestrus detection and calf gender control in beef cows. Anim. Reprod. Sci., 46: 27-34.

[32] Yılmaz I., Eyduran E.A., Kaygısız A., 2010. Determination of some environmental factors related to gender ratio of Brown Swiss calves. J. Anim. Plant Sci. 20, 164-169. 